\title{
Thank You and Welcome
}

Mark Byra officially completed his 2-year term as editor-inchief, following a 2-year term as incoming editor-in-chief. On behalf of Journal of Teaching in Physical Education (JTPE), we offer our thanks and appreciation to Mark for his hard work and dedication to advancing JTPE in the field. In particular, we thank him for his efforts in overseeing a number of important special issues, monographs, and papers published over the past 4 years and others still to be published in the next volume.

With Dr. Byra's departure, Dr. Heather Erwin from the University of Kentucky begins a 2-year term as incoming editor-in-chief (2020-2022), followed by a 2-year term as editor-in-chief (2022-2024). Heather brings a wealth of research and experience to this position, having served as an author and JTPE's 2014 Reviewer of the Year. Additionally, she has been an academic editor for PLOS One and has been on the Journal of Physical Education, Recreation and Dance editorial board. We look forward to Heather's leadership in the position of co-editor.

Bryan McCullick, Editor-in-Chief 